\title{
First Language Interference On English Use
}

\author{
(A Study of First Year Students at Senior High School in Bengkulu, Indonesia \\ Academic Year 2019) \\ Pebri Prandika Putra \\ pebriputra@iainbengkulu.ac.id \\ IAIN Bengkulu, Indonesia \\ Abstract
}

\begin{abstract}
This study aimed to investigate and analyze in depth about first language interference on English use of First Year Students at Senior High School in Bengkulu City. The research method was Qualitative Descriptive. This research is able to capture and provide the description clearly of a language phenomenon that is the object of study. The study was conducted in 4 high schools in Bengkulu city such as SMAN 7, MAN 2, SMKS 11 Serunting 2 and SMA Pembangunan. The data was analyzed totaling 30 data and completed with a questionnaire test. The results of the study were conducted by testing 5 types of interference namely lexical interference, semantic interference, idiomatic interference, collocation interference and cultural interference. From 30 data that investigated and analyzed showing $80 \%$ of errors occurred at the level of lexical interference, $5 \%$ semantic interference, $10 \%$ collocation interference, $5 \%$ cultural interference and $0 \%$ idiomatics interference. Lexical interference is more dominant in this study because the mastery of the first language is more dominant in the process of learning foreign language.
\end{abstract}

Key words: Language, Interference 


\section{Introduction}

Nowadays it is undeniable that English continues to develop into a language that determines the future of a nation. International language connected all aspects of life with other nations (Sinha, Banerjee, Sinha, \& Shastri, 2009). It is certain that there is no other way to master science without linguistics. The first language is the language that mastered by the learner before learning a foreign language. First language has different names such as, mother tongue, native language and primary language (Sinha et al., 2009). The Indonesian curriculum still uses English as a foreign language which is only used at an academic aspect.

Error in using a foreign language is considered reasonable because the application is also useless. Bahasa becomes the first language that mastered by students so that its influence when learning a foreign language will automatically affect them directly. This strong influence in the Indonesian language in the process of learning foreign language called interference. The results of first language learning are positive and negative transfers (see Lekova, 2010: 320). This transfer occurs when people use foreign languages both oral and written. If the influence of the first language is stronger there will be a negative transfer of foreign languages and the other way around (Ellis. 1994).

According to Heaton (1988:135), the writing skills are hard and sometime complex to deliver, requiring mastery not only of lexical grammatical and rhetorical device but also of conceptual, context and judgmental parts. The following analysis attempts to group the many and varied skills necessary for writing good prose into five general components or main areas. First, Language uses: the ability to write correct and appropriate sentence. Second, Mechanical Skills: the ability to use correctly those conventions peculiar to the written language -e.g. punctuation, spelling. Third, Treatment of contents: the ability to think creatively and develop thoughts, excluding all irrelevant information. Fourth, Stylistic skills: the ability to manipulate sentence and paragraphs, and use language effectively. Fifth, Judgment skills : the ability to write in an appropriate manner for a particular purposes with a particular audience in mind, together with an ability to select, organize and order relevant information Heaton (1988:135).

Writing well is not just an option for young people-it is a necessity. Along with reading comprehension, writing skill is a predictor of academic succes and a basic 
requirement for participation in civic life and in the global economy (Graham \& Perin, 2017:3). In fact education system does not support to develeop students writing skill where students just learn foreign language as a part of curriculum without emphasizing the skill. Bahasa as the first language is conquered by students. They master it both of spoken and written.

Actually the students are interested to learn English, but sometime they got difficult in learning writing subject because they have problems in comparing Bahasa and English. They should solve their problems by learning English and able to contrast them. English and Bahasa had a symbol of the sound that definitely symbolizes a certain sense. Thus, it is denoted a sense, a concept, an idea or a thought that is to be conveyed in the form of the sound. Because the symbols that refer to a concept, idea or thought, it can be said that language has meaning (Chair: 2007:35).

\section{Theoretical Studies}

\section{Language Interference}

The classification of language interference that occurs will be analyzed based on the statement of Thorovsky (2009: 86) which categorizes language interference into several types such as:

\section{Lexical interference}

This interference arises when the lexical units of the source language are evident in the lexical units of the target language but that is not equivalent. Thorovsky states that the translation get lexical interference may be able to have the same sentence and word structure individually but they are very different in semantic aspect.

\section{Semantic interference}

This interference arises when there are overlapping lexical meanings between the lexical meaning of the source language unit and the lexical meaning of the target language unit which is basically only partially equivalent. Sometimes there are translators who in the translation process are only satisfied with the first meaning obtained through a dictionary and do not look for the meaning of a text as a whole based on context.

\section{Idiomatic interference}

This interference arises when the translator misinterprets the meaning of an idiomatic expression. An idiom is a word or sentence whose meaning is very complex. 
It cannot just translate an expression or idiom of a statement without thinking about the context and atmosphere of the sentence itself. Idioms cannot be translated literally.

\section{Interference collocation}

This interference is actually a part of semantic interference, but the difference is the level. Collocation interference occurs at the level of collocation rather than at the level of individual words.

\section{Cultural interference}

This interference arises when the translator cannot recognize the existence of cultural elements that arise when creating a work.

\section{Writing Aspects}

Writing is one way to express ideas, feelings, thoughts, and opinions in written form. In order to master in writing, the students must know the rules and put them on the correct language at the different form of writing. According to Wallace (1986:15), writing is the final product of several separate acts that are hugely challenging to learn simultaneously. Among these separable acts are note taking, identifying a central idea, outlining, drafting and editing. As Lyons and Heasley (1994 : 3) stated writing is clearly a complex process, and competent writing is frequently accepted as being the last language skill to be acquired. Actually, the students master it through practice and the study of the rules and they learn how to execute certain forms, personal essays, research paper and critical argument. Moreover, mastered in writing need many practices from the students and counseling from the teachers. It must be learned for a long time.

Writing is a form of thinking, because writing is transforming the writers' thought or ideas into written text. In other word, what the writers wants to say to the reader can be written in the written form. Writing is a way of putting ideas in correct order. Before writing the writers need to think about many things. The messages of the ideas of the writers in order to be understood by the reader, the writers also must use correct written language. Ur (1996:163) stated that the purposes of writing is to express ideas and convey of messages to the reader, so the ideas themselves should arguable and the writers should also pay attention to formal aspect of handwriting, correct spelling, punctuation, grammar and vocabulary. Moreover Heaton (1975) stated that writing is kind of effort to transfer oral language into written language and than the language ability in an effort in expressing idea, mind or sense in written language correctly. 
Technical writing is characterized by certain formal elements, such as its scientific and technical vocabulary, its use of graphic aids and its use of conventional report forms. According to Gordon and Walter (1962:4) technical writing is writing in which there is a relatively high concentration of certain complex and important writing techniques, in particular description of mechanisms, description of a process, definition, classification and interpretation. Still in Gordon and Walter (1962 : 13), there are many more than five principles involved in good technical writing, but the five stated below are so important that they may be taken as a foundation on which further development rest :

1. Always have in mind a specific reader, real or imaginary, when you are writing a report and always assume that he is intelligent but uninformed.

2. Before you start to write, always decide what the exact purpose of your report is; and make sure that every paragraph, every sentence, every word, makes a clear contribution to that purpose and makes it at the right time.

3. Use language that is simple, concrete and familiar.

4. At the beginning and end of every section of your report check your writing according to this principle : "first you tell the reader what you are going to tell him, then you tell him what you have told him."

5. Make your report attractive to look at.

\section{The Concept of Contrastive Analysis}

Contrastive analysis is an activity that attempts to compare the structure of First Language (FL) with Second Language (SL) and to identify the differences between the two languages. These differences may be used as the basis to forecast or predict language learning difficulties to be faced by the students (Tarigan, 1994:4). The biggest obstacle in the process of mastering a second language (SL) was the mixing system of first language (FL) to second language (SL) system. Contrastive analysis tried to bridge this difficulty by contrasting both the language system to predict the difficulties.

Contrastive analysis includes two aspects: linguistic aspects and psychological aspects. Linguistic aspects related to the use of the structure and phonological structure, because it is assumed that it was instrumental in teaching SL (James: 180:28). There is a contrastive analysis of linguistics and psychology. It is believed that linguistics 
concerned with the nature of language and learning not only with a psychological problem. Contrastive analysis deals with learning a second language (SL) which requires a psychological component (James: 180:28). (Jacobovits 2008: 38) stated that language skills in a second language is determined by many factors, including the interference. Jacobovits also stated language skills in a second language is a cumulative function of the mother language skills, training in the mother tongue, and practice in second language.

\section{Research Methodology}

Based on the problems raised in this study, the type of research was descriptive qualitative. This research is able to capture and provide clear and thorough descriptions of a language phenomenon that is the object of study. Data analysis is performed after the data was collected properly. Data was collected by test results and questionnaires given to students in High Schools in Bengkulu City. The qualitative analysis consists of parts of a methodologically. The steps are:

1. Analyzing the results of student writing

2. Analyzing the questionnaire given to students

3. Summing up the factors causing Interference

4. Making a complete discussion of the data along with conclusions and recommendations

\section{Results and Discussion}

The results of this research conducted by the lecturers that showed that Bahasa intererence on English use at Students of Senior High School in Bengkulu City. Researchers found that there are still many fundamental mistakes on the use of English classified as simple texts. The existence of these mistakes caused concern about the level of students' understanding of learning English in class. It Does not deny that this inseparable from the teaching and facilities owned by the school and students themselves.

Types of Bahasa Interference toward English found in this study that elaborated based on the type of error and classified based on Thorovsky's statement (2009: 86) which categorizes language interference into several types such as lexical interference, semantic interference, idiomatic interference, collocation interference and cultural interference. The researcher gave several topics in Indonesian which students then wrote 
into a series of English sentences. The topic is universal depending on students' reading and writing interests.

There are 4 schools, namely SMAN 7 Bengkulu City, MAN 2 Bengkulu City, SMKS 11 Serunting 2 Bengkulu City and SMA Pembangunan Bengkulu City. It Shows that indeed Independent High Schools are influnced by language interference, namely SMKS 11 Serunting 2 Bengkulu City and SMA Pembangunan Bengkulu City.

There are several things that need to be considered in connection with interference, as follows:

1) Interference in communication due to interference can usually be reduced or eliminated by bilingual scholars by using skills in accordance with the language used by the lecturers;

2) The occurrence of interference seems to depend on fatigue, stress, interlocutors, and so on.

3) Fluent or almost fluent bilingual in the two languages used often shows two-way interference, each language influencing each other, at least in the lexical field. People who can use two or more languages interchangeably for different purposes are essentially linguists. The greater the number of people do this one, the more intensive the contact between the two languages they use. This contact creates mutual influence, which manifests in the application of the first language (B1) on the use of the second language (B2) when it uses the first language (B1). One of negative impacts from the practice of using language interchangeably is the chaos on the use of language which is better known as interference.

Rusyana (1984: 70) says that interference takes an element from a language that needed in relation to other languages; the application of two systems simultaneously to a language element; deviations occur in a person's speech due to the introduction of two or more languages. The author also analyzes and classifies any errors that arise because of this interference factor, namely;

\begin{tabular}{|l|l|l|l|}
\hline & Interferences & Number & $\%$ \\
\hline 1 & Lexical Interference & 23 & $76 \%$ \\
\hline 2 & Semantic Interference & 2 & $6,7 \%$ \\
\hline
\end{tabular}




\begin{tabular}{|l|l|l|l|}
\hline 3 & Idiomatics Interference & 0 & - \\
\hline 4 & Collocation Interference & 3 & $10 \%$ \\
\hline 5 & Culture Interference & 2 & $6,7 \%$ \\
\hline
\end{tabular}

The data above shows that indeed lexical errors are very dominant on students' writing achievement in English. Lexical is related to words that have real meanings. But the lexical of every language is different. Lexical is a lexicon or lexeme or word that stands alone, it is not in context and independent of context. Some interpret that lexical is the meaning contained in dictionary. That is not always true based on the following considerations. 1) The dictionary does not only contain lexical meanings. A number of possible meanings are displayed in context so that they are not lexical meanings. 2) If the dictionary is interpreted as text that contains words and their meanings, the definition does not apply to languages that do not have a dictionary. In fact, lexical meaning is always in a language even though the language does not have a dictionary yet (Hardiyanto, 2008: 21)

Likewise, lexical semantic errors also often occur due to diction and error in terms of meaning. Semantics contains of "the study of meaning". A study of meaning is part of linguistics. Like sound and grammar, the component of meaning in this case also occupies a certain level. That is the sound component occupies as the first level, grammar is second level while the meaning component occupies as the last level. The relationship among three components because Language is system of conventional spoken, manual, or written symbols by means of which human beings, as members of a social group and participants in its culture, express themselves. (Aminuddin 1988: 15).

\begin{tabular}{|l|l|l|}
\hline $\mathrm{N}$ & & \\
\hline 4 & $\begin{array}{l}\text { My cat is so funny, she } \\
\text { name is Mary Sella. I like to } \\
\text { play with she everyday. My } \\
\text { cat is so beautiful. She hair } \\
\text { is white and eyes is blue. } \\
\text { My cat likely to clawmy } \\
\text { sofa. I very angry with she. } \\
\text { But because she so funn, I } \\
\text { apologie her. My cat is little } \\
\text { angel in my heart. I am very } \\
\text { miss she. }\end{array}$ & Lexical Interence \\
\hline
\end{tabular}


The paragraph was written by the student / respondent above contains errors and lose the true meaning. In English a mistake in grammar means the meaning will disappear. The first mistake in the sentence I like to play with she everyday. In that sentence, it can be seen that the respondent cannot write the pronoun correctly. The pronoun She should be Her but the correct pronoun is $i t$.

Sentences contain the interference element She hair is white and eyes is blue. The sentence can be understood lexically but it contains the wrong element grammatically. The sentence has a confusion in the use of the subject. The correct pronoun was its. Then the correct sentence is Its hair is white and its eyes is blue. This error is reasonable because in the Indonesian language do not have strict rules for subject like in English . 'Dia' subject used for all subjects without exception. But in English there are binding rules that cannot be abandoned.

The sentence case is an error or passes an important word that is to be. the sentence above, which is I very angry with she. But because she is so funny. Where there is omission to be that will damage the sentence structure and lexical meaning. The sentence should be I am very angry to it. It is because she is so funny. Improvements need to be considered are the use of pronouns and subjects that must be more precise so as not to cause double errors both meaning and grammatical.

The important error is the inconsistency of respondents in using of the tenses. The tense in English is very binding to create true meaning. While Indonesian does not have rules or patterns of tenses because the nature of Bahasa is contextual meaning. My father was tall, white and had short black hair. The sentence was wrong in terms of its shape because to describe something that keeps happening, it must use the present tense form, not past tense. So the correct sentence was My father is tall, white and had short black hair.

Likewise lexical interference, semantic interference also often occur due to diction and error in terms of meaning. Semantics is "the study of meaning". Semantics is part of linguistics like meaning, sounds and grammar.

\begin{tabular}{|l|l|l|}
\hline $\mathrm{N}$ & & \\
\hline 16 & $\begin{array}{l}\text { We have to slow down because } \\
\text { there is a sleeping police on the } \\
\text { road. }\end{array}$ & Semantics Interference \\
\hline
\end{tabular}


In the Indonesian language, the term "Polisi Tidur" is used to refer to bumps on the highway that are deliberately installed so that the speed of the vehicle can be slowed. Actually there is a separate term for the meaning of "Polisi Tidur," which is road bump. Here students enter elements of Bahasa into English so semantic interference occurs in this case.

Cultural interference in the writing process often occurs sometimes students can not distinguish the right cultural words in making a sentence

\begin{tabular}{|l|l|l|}
\hline $\mathrm{N}$ & & \\
\hline 23 & We will be asked to show our & Cultural Interference \\
Citizenship Card when we are & \\
going to get on the plane. & \\
\hline
\end{tabular}

Each country has different terms to describe the name of the identity card. In European countries identity cards are generally called "ID cards," whereas in Indonesia they are called "Kartu Tanda Penduduk." Students used the term 'Citizenship Card', which should be an "Identity Card." This is influenced by a lack of knowledge held students because literally "Kartu Tanda Penduduk" means "Citizenship Card."

The Fourth was a collocation error. Collocation is the meaning associated to the use of several leksem in a area (Hardiyanto, 2008: 26). Here are a few examples of how you can make collocations using a single adjective. Deep: Deep feeling, deep pockets, deep sleep, deep trouble. Heavy: Heavy rain, heavy sleeper, a heavy drinker, heavy snow, heavy traffic. Strong: Strong smell, strong sense, strong denial.

\begin{tabular}{|c|c|c|}
\hline $\mathrm{N}$ & & \\
\hline 18 & $\begin{array}{l}\text { We needed about three hours to } \\
\text { reach the destination because there } \\
\text { was a traffic jam on the road. Thank } \\
\text { god we finally made it. }\end{array}$ & $\begin{array}{l}\text { Collocation } \\
\text { Interference }\end{array}$ \\
\hline
\end{tabular}

The sentence above contains collocation, which are two words that paired and often used together. Error in the data is the word "need" which should "take" because in the English structure, the phrase "need three hours" is not found. The error is influenced 
by the writers' perception that in Indonesian the word "Membutuhkan" can be used to explain the duration of time that needed to do something. This contradicts to the structure in English.

The idiomatic problem is also an obstacle because the two languages have different idiomatic types. Indonesian idioms are called agglutinative and English is infexsi systems. The idiomatic expression of Indonesian is a distinctive construction in a language where one element cannot be removed or replaced. Idiomatic expressions are words that have idiomatic characteristics which are not affected by the rules of language economics.

Example: Some examples of the use of Indonesian idiomatic expressions are as follows:

Menteri dalam negeri bertemu Presiden SBY (wrong)

Menteri dalam negeri bertemu dengan Presiden SBY (right)

English Idiom is a combination of several words in English which are a parable or not true meaning. Example I slept like a dog.

In this research the researcher could not find out the idiomatic interference made by students. The reason is students could not understand yet related to idiomatic use.

\section{Conclusion}

English has strong characteristics with a strict system of language use. This is evident starting from the level of the smallest morpheme English has its own rules. In the past tense pattern, the English language has strict rules, if we want to make a past sentence we must use the past verb and use different auxiliary verb as well. Meanwhile, Bahasa is not as strict as English because Bahasa emphasizes acceptance and readability in each sentence produced.

It can be Concluded that every language in this world must have its own system, both morphological and phonological systems. Throughout the history of human life there has never been a common language because its essential language is to develop following human civilization. Bahasa is a language that is still new as evidenced by the fact that there are still many foreign words which have been adapted into the official language of Indonesia. But it does not mean with these differences humans can not develop their life. Humans are increasingly continuing to learn foreign languages for the advancement of time. 


\section{References}

${ }^{1}$ Aminudin. 2015. Pengantar Apresiasi Karya Sastra. Bandung: Sinar Baru Algensind

${ }^{2}$ Chaer, Abdul.2007. Linguistik Umum. Jakarta: Rineka cipta

${ }^{3}$ Ellis, Rod. 1989. Understanding Second Language Acquisition. Oxford: Oxford University Press

${ }^{4}$ Graham, Steven \& Perin. 2007. Writing Next. Washington,DC : Alliance for Excellent Education

${ }^{5}$ Hardiyanto. 2008. Leksikologi. Yogyakarta : Kanwa

${ }^{6}$ Heaton, JB. 1998. Writing English Language Test. New York : Edinburg Gate

${ }^{7}$ James, Carl. 1980. Contrastive Analisis. Harlow: Longman Group.

${ }^{8}$ Kridalaksana, Harimurti. 2001. Kamus linguistik. Jakarta: Gramedia Pustaka Utama.

${ }^{9}$ L.A, Jacobovits. 1970. Foreign Language Learning: A Psycholinguistics Analysis of The Issue. Rawly Mass: Newbury House Publisher

${ }^{10}$ Lekova, B. 2010. Language interference and methods of its overcoming in foreign language teaching. Trakia Journal of Sciences. 8 (3). 320-324.

${ }^{11}$ Mills, Gordon \& Walter, Jhon. 1998. Technical Writing. New York : The University of Texas

${ }^{12}$ Rusyana, Yus. 1975. "Interferensi Morfologi pada Penggunaan Bahasa Indonesia anak-anak Yang berbahasa pertama bahasa Sunda Murid SD di Daerah Prov. Jabar”. Jakarta : Disertasi

${ }^{13}$ Tarigan, Henry Guntur. 1990. Pengajaran Analisis Kesalahan Berbahasa. Bandung : Angkasa 
${ }^{14}$ Thorovský, Martin. 2009. Lexical Linguistic Interference in Translations of ScienceFiction Literature from English into Czech. Ostrava Journal of English Philology, vol. 1: 86-98

${ }^{15}$ Sinha, A., Banejee, N., Sinha, A., \& Shastri, R. 2009. Interference of first language in the acquisition of second language. Journal of Psychology And Counseling, 1(7), $117-122$

${ }^{16}$ Ur, Penny. 1996. A Course in Language Teaching. Cambridge University Press. New York : Sage Publications 